\title{
Reconstruction of Maxilla and Midface with Microvascular Free Flaps
}

\author{
Shin Hye Kim ${ }^{1}$, Dong Wook Kim${ }^{1}$, Heejin Kim¹, \\ Dong-Young Kim ${ }^{1}$, Chae-Seo Rhee ${ }^{2}$ and J. Hun $\mathrm{Hah}^{1}$ \\ ${ }^{I}$ Department of Otorhinolaryngology-Head and Neck Surgery, Seoul National University Hospital, \\ Seoul National University College of Medicine, Seoul; and ${ }^{2}$ Department of Otorhinolaryngology-Head and Neck Surgery, \\ Seoul National University Bundang Hospital, Seoul National University College of Medicine, Seongnam, Korea
}

\section{상악절제술 후 다양한 유리 피판을 이용한 상악 재건}

김신혜 $^{1} \cdot$ 김동욱 ${ }^{1} \cdot$ 김희진 $^{1} \cdot$ 김동영 ${ }^{1} \cdot$ 이재서 ${ }^{2} \cdot$ 하정훈 $^{1}$

서울대학교 의과대학 서울대학교병원 이비인후과학교실, ${ }^{1}$ 서울대학교 의과대학 분당서울대학교병원 이비인후과학교실 ${ }^{2}$

\author{
Received July 12, 2013 \\ Revised August 6, 2013 \\ Accepted August 19, 2013 \\ Address for correspondence \\ Dong Wook Kim, MD \\ Department of Otorhinolaryngology- \\ Head and Neck Surgery, \\ Seoul National University Hospital, \\ Seoul National University \\ College of Medicine, 101 Daehak-ro, \\ Jongno-gu, Seoul 110-744, Korea \\ Tel $+82-2-2072-2441$ \\ Fax $+82-2-745-2287$ \\ E-mail treu24@naver.com
}

Background and Objectives The aim of this study is to report the clinical results of maxillary reconstruction with free flap.

Subjects and Method Patients who had undergone free flap reconstruction after maxillectomy from January 2009 to January 2013 were included in the study. The medical records of the maxillary defect classification, the type of flap used for reconstruction, follow-up results including the survival rate of flap and postoperative complications were analyzed retrospectively. Results A total of 13 cases underwent maxillary reconstruction after maxillectomy. Maxillary resection were classified from Ia to $\mathrm{V}$ according to the Brown classlification system, and various composite flaps including rectus abdominis, latissimus dorsi, radial forearm and iliac crest were used. One case (class Ia) was reconstructed with a radial forearm free flap while six cases (classes II, III) were reconstructed with the osteomuscular free flap type, such as iliac crest. Another six cases needed orbital exenteration (class IV, V) and were reconstructed with a soft tissue free flap type, such as a rectus abdominis or latissimus dorsi. Of the 13 cases, four patients had postoperative wound dehiscence and two had preoperative radiotherapy. In all 13 cases, the flaps survived.

Conclusion Maxillary reconstructions were performed successfully with various free flaps according to the extent of maxillary defect.

Korean J Otorhinolaryngol-Head Neck Surg 2013;56:642-6

Key Words Free flap · Iliac crest · Maxillary defect · Maxillectomy $\cdot$ Reconstruction.

\section{서 론}

상악의 원발부 악성 종양이나 주변에서 발생하여 상악을 침범하는 악성 종양을 적출한 후에는 중앙 안면부의 매우 심 각한 미용적, 기능적 후유증이 남게 되므로 상악절제술 후 적 극적인 상악 재건이 필수적이다. 구개 결손의 경우에는 상악 및 인두 폐색장치(obturator)와 같은 치과 보철물로 재건이 가능하다. 폐색 보철물을 이용하면 상악 구개 결손의 폐쇄를
통해 치아의 회복, 과대 비성의 감소, 구음장애의 어느 정도 회 복이 가능하며, 수술 시간이 짧고, 수술 후 재원 기간이 짧으 며, 상악절제술 후 재발 여부 평가가 용이하다는 장점이 있다. 그러나 폐색장치만으로는 수술 후 과대 비성과 구음장애 의 해결에 한계가 있다. 또한 폐색장치 사용시 통증, 궤양, 출 혈, 악취와 비강으로의 음식누출, 구강으로의 비루 등이 발 생하고 장착과 제거, 세척이 불편할 수 있으며, 결손부가 클 경우 효과적으로 유지하기 힘들다.,2) 이처럼 보철물을 이용한 
재활은 치료자의 입장에서는 간편하지만 환자의 입장에서는 많은 불편함이 남는다. 또한 보철물을 사용하여 구개를 열어 놓으면 표면에서의 재발을 발견하기는 쉽지만 심부 재발 소 견은 발견하기 어려워 MRI 촬영 등의 추적 관찰이 필수적이 며, 심부 재발의 경우에는 재수술로 완전 절제가 불가능한 경 우도 많다. 따라서 철저하게 원발 부위를 절제한 후, 수술을 통해 적극적으로 재건해 주는 것이 장기적으로 환자에게 유리 할 수 있다.

현재 상악 절제의 범위에 따라 복직근 피판(rectus abdominis flap), 광배근 피판(latissimus dorsi flap), 요측 전완부 피판(radial forearm flap) 등의 연부 조직 유리 피판과 장골 능(iliac crest), 비골(fibula), 요골 전완(radius), 혹은 견갑골 (scapula)을 포함하는 골근육 유리 피판(osteomuscular free flap)과 같은 다양한 복합 유리 피판(composite free flap)을 상악 재건술에 사용하고 있다. 아직 상악절제술 후 유리 피판 을 이용한 재건에 있어 최적의 방법에 대한 일치된 견해가 없 어, 이에 그 경험을 정리하고 나아가 재건 방법의 선택을 위한 알고리즘을 제시하고자 한다.

\section{대상 및 방법}

2009년 1월부터 2013년 1월까지 본원 이비인후과에서 한 명 의 술자(HJH)에게 상악절제술 후 유리 피판을 이용한 상악 재건술을 시행 받은 환자를 대상으로 하였다. 의무 기록을 후향적으로 분석하였고 상악 결손의 분류, 재건에 이용된 유

Table 1. Classification of vertical and horizontal maxillectomy and midface defect by Brown JS and Shaw RJ (Adopted from Brown and Shaw, 2010)

\begin{tabular}{cc}
\hline Classification & Defect \\
\hline $\begin{array}{c}\text { Vertical classification } \\
\text { I }\end{array}$ & $\begin{array}{c}\text { Maxillectomy not causing an oronasal fistula } \\
\text { (very limited) }\end{array}$ \\
III & $\begin{array}{c}\text { Maxillectomy not involving the orbit } \\
\text { with orbital retention }\end{array}$ \\
IV & Maxillectomy with orbital enucleation \\
Or exenteration & Orbitomaxillary defect \\
VI & Nasomaxillary defect \\
Horizontal classification & Palatal defect only, not involving dental \\
a & alveolus \\
b & Less than or equal to $1 / 2$ unilateral \\
c & Less than or equal to $1 / 2$ bilateral or transverse \\
d & anterior
\end{tabular}

Letters refer to the increasing complexity of the dentoalveolar and palatal defect, and qualify the vertical dimension
리 피판의 종류, 유리 피판의 생존률 및 수술 후 합병증을 포 함한 수술 결과 등을 평가하였다. 상악 결손의 평가는 Brown 의 분류를 이용하였는데, ${ }^{3)}$ 수직 및 수평 성분으로 구분하여 안와 포함 여부에 따라 수직 성분은 6개로 나뉘었으며, 수평 성분은 구개와 치조골 능선의 결손 정도에 따라 4단계로 나 누었다(Table 1).

\section{결 과}

연구 기간 동안 총 13 예의 상악절제술 후 상악 재건술이 시행되었다. 남자는 11 명, 여자는 2 명이었으며, 평균 나이는 58.8(41 72)세였다. 수술 전 방사선치료를 받은 환자가 7명이 었는데, 주로 안구적출이 필요할 정도로 원발 부위의 병기가 진행한 환자들이었다. 상악절제술의 분류는 Brown class Ia, IId, IIIb, IIId, IVb, IVd, V 등으로 다양하였고, 재건술에 사 용된 유리 피판은 장골능 골피부근육 유리 피판, 요측 전완부 유리 피판, 복직근 유리 피판, 광배근 유리 피판이었으며, 결손 형태에 따른 유리 피판의 종류는 Table 2 와 같다.

13예의 상악절제술을 시행 받은 환자 중, 암종이 안구까지 침범한 6예(class IV, V) 모두에서 안구적출을 시행한 후 복직 근 피판(4예), 광배근 피판(2예)의 연부조직 유리 피판을 이용 하여 상악 재건을 시행하였다. 안구 침범 없이 안와에만 암종 침범이 있어 안와륜(orbit rim) 및 치조능선(alveolar ridge)을 절제한 5예(class II, III)의 경우, 장골능 골근육 또는 골피부 근육 유리 피판을 상악 재건에 사용하였다. 그리고 안와 침범 이 없던 2예 중 치조능선 침범 없이 구개의 작은 크기의 결손 만 있던 증례(class Ia)는 요측 전완부 피판으로 재건하였으 나, 치조능선 대부분을 포함한 큰 구개 결손의 경우(Brown 분류 IId)에는 장골능 골피부근육 유리 피판을 사용하였다.

총 13예 중, 복직근 피판 재건 3예 및 광배근 피판 재건 1예 에서 수술 후 창상 벌어짐이 발생하였다. 그 4예 중 2예는 수 술 전 방사선 치료를 받은 적이 있었다. 3예에서는 국소 마취 하에 벌어진 창상을 재봉합 하였으나, 복직근 피판을 시행한 1 예에서 수술 후 30 일경 피판 가장자리의 괴사 및 창상 벌어 짐 소견을 보여 전신마취 하에 wound exploration을 시행하 여 장액종(seroma) 제거 및 창상 변연 절제를 하였다. 1 예의 광배근 피판 증례에서는 공여부에서 혈종이 발생하여 국소 마취 하에 제거하였다. 그 외의 피판과 관련된 합병증은 없었 으며 모든 유리 피판은 생존하였다(survival rate: 100\%).

\section{고 찰}

상악 재건시 일반 재건술과 마찬가지로 미용적인 면과 기 
Table 2. Patient profile of maxillary reconstruction

\begin{tabular}{|c|c|c|c|c|c|c|c|c|c|c|c|}
\hline Case & Sex & Age & Pathology & $\begin{array}{l}\text { Preop } \\
\text { RT }\end{array}$ & $\begin{array}{c}\text { Orbital } \\
\text { exenteration }\end{array}$ & $\begin{array}{c}\text { Intracranial } \\
\text { extension }\end{array}$ & $\begin{array}{c}\text { Skin } \\
\text { defect }\end{array}$ & $\begin{array}{l}\text { Defect } \\
\text { class* }\end{array}$ & Flap & Complication & $\begin{array}{c}\text { Hospital } \\
\text { stay (days) }\end{array}$ \\
\hline 1 & $M$ & 64 & PNST & Yes & & & & Illd & IC & & 15 \\
\hline 2 & $\mathrm{~F}$ & 55 & $\mathrm{ACC}$ & & & & & IIId & IC & & 21 \\
\hline 3 & M & 63 & $\mathrm{ACC}$ & & & & & Illd & IC & & 15 \\
\hline 4 & M & 57 & SCC & & & & Yes & Illd & IC & & 22 \\
\hline 5 & M & 55 & SCC & & & & & IIId & IC & & 18 \\
\hline 6 & M & 55 & PTCL & Yes & & & & Ild & IC & & 15 \\
\hline 7 & M & 52 & SCC & Yes & & & & la & RF & & 15 \\
\hline 8 & M & 62 & $\mathrm{SCC}$ & Yes & Yes & Yes & Yes & $\mathrm{IVb}$ & RA & & 18 \\
\hline 9 & M & 72 & SC & & Yes & Yes & Yes & IVd & RA & $\begin{array}{l}\text { Wound dehiscence \& } \\
\text { seroma }\end{array}$ & 22 \\
\hline 10 & $\mathrm{~F}$ & 70 & MFH & Yes & Yes & Yes & Yes & $\mathrm{IVb}$ & RA & Wound dehiscence & 31 \\
\hline 11 & M & 60 & $\mathrm{ACC}$ & Yes & Yes & Yes & & $\mathrm{IVb}$ & RA & Wound dehiscence & 34 \\
\hline 12 & M & 59 & MFS & & Yes & & & IVd & LD & Wound dehiscence & 26 \\
\hline 13 & M & 41 & SNUC & Yes & Yes & Yes & & $\vee$ & LD & Hematoma at donor site & 32 \\
\hline
\end{tabular}

*Brown classification. PNST: peripheral nerve sheath tumor, SCC: squamous cell carcinoma, ACC: adenoid cystic carcinoma, PTCL: peripheral T-cell lymphoma (maxillary defect due to radionecrosis), SC: sebaceous carcinoma, MFH: malignant fibrous histiocytoma, MFS: myofibroblastic sarcoma, SNUC: sinonasal undifferentiated carcinoma, RT: radiotherapy, IC: iliac crest, RF: radial forearm, RA: rectus abdominis, LD: latissimus dorsi

능적인 면을 모두 고려해야 한다. 상악 재건의 목표는 첫째, 안구의 위치, 용적, 안검 기능의 변화를 최소화하며 안구 내 용물을 충분히 지지해야 한다. 만약 안구를 적출한 경우에 는 안와를 미용적으로 잘 만들어 주어야 한다. 둘째, 비강 기 도를 유지하고 비강과 구강을 잘 분리해야 하며, 이는 저작 기 능과 발성에 도움이 되고, 치아 재활을 가능하게 한다. 셋째, 반 대쪽 얼굴과 대칭이 되는 안면 윤곽을 만들어 주어야 한다. ${ }^{4}$

상악 재건에는 다양한 방법이 사용될 수 있는데, 그 방법의 선택에 있어 가장 중요한 인자는 그 병원에서 제공 가능한 방 법의 다양성이라 할 수 있다. 재건을 담당한 이비인후과나 성 형외과 의사가 선호하는 재건 방법에 따라 그 선택은 크게 달 라질 수 밖에 없다. 상악 결손의 범위와 위치에 따라 가능한 다양한 재건 방법 가운데 재건을 담당한 외과의가 그 방법을 선택하기 때문에, 아직은 누구나 인정하는 이상적인 방법은 없 으며 논문마다 또는 보고자마다 다른 선택을 하고, 그 선택 알 고리즘도 차이가 있다. ${ }^{2,3,5,6)}$

구개 및 상악의 재건에 있어 유리 피판의 공여부를 선택할 때 조직 결손 부위의 부피와 필요한 피판의 수에 따라 다양 한 결정을 해야 한다. 안면부의 피부 및 연부 조직과 구개의 결손시 근육과 지방층이 풍부하며 크기가 큰 광배근 피판과 복직근 피판이 요측 전완부 피판보다 유리할 것이다. 반면 조 직 결손 부위의 부피가 작고 피부의 재건이 중요한 경우는 요측 전완부 피판이 적절할 것이다.

저자는 기존의 문헌 고찰 및 지금까지의 경험을 토대로, 안 구 적출을 시행하는 경우에는 복직근 또는 광배근과 같은 큰 부피의 근육을 이용한 연부조직 유리 피판을 사용하였고, 안

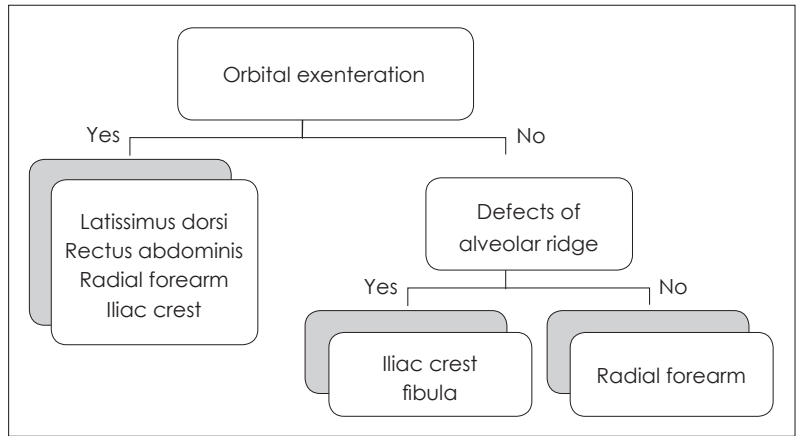

Fig. 1. Current personal options of free flaps in maxillary reconstruction. Algorithm for the choice of free flap in maxillary reconstruction is described on flow chart. The author preferred the reconstruction with iliac crest free flap in defects of alveolar ridge or orbit wall.

구 적출을 하지 않지만 안와연 또는 치조 능선의 결손이 큰 상악절제술 시행 환자에서는 장골능 골근육 유리 피판을 이 용한다는 알고리즘에 따라서 상악골 재건 방법을 선택하였 다(Fig. 1)

장골능은 전체 두께를 채취하여 이식하였고, 공여부는 주 로 상악골 결손과 같은 쪽을 사용하였다. 장골능 유리 피판은 혈관경이 짧아서 장골능 유리 피판 재건 시행 초기 2예에서는 외경 정맥을 채취하여 안면 동맥, 안면 정맥과 장골능 유리 피 판의 혈관들 사이에 연결하였으나, 이후에는 수용부 혈관을 찾는 데 더 많은 시간을 할애하여 얼굴 안쪽에서 혈관을 찾 아 연결하였다. 구개의 재건에 있어 장골능에 붙여서 채취한 내복사근을 이용하였는데, 추적 관찰시 6개월 후 얇은 구개 점막으로 변화되고 적응되는 것을 관찰할 수 있었다(Fig. 2).

상악절제술 전 방사선 치료는 유리 피판의 생존 혹은 창상 
벌어짐과 같은 합병증에 영향을 줄 수 있는데, ${ }^{7)}$ 이번 연구에 서도 창상 벌어짐을 보인 4예 중 2예가 수술 전 방사선 치료 를 시행 받았었다. 또한 근치적 상악절제술 후 정상 치유 과정 과 보조 방사선 치료(adjuvant radiation therapy)도 피판 부피 감소 및 수축을 일으킬 수 있으므로 이를 고려하여 재건을 해 야 하며 피판이 중력에 의해 하강하면서 창상 벌어짐이 발생 하는 것도 고려하여야 한다. ${ }^{8)}$

장골능 골피부 혹은 골근육, 골근육피부 유리 피판은 1996년 Brown ${ }^{9}$ 이 장골능 유리 피판을 상악 재건에 사용한 것 을 처음 보고한 이후, 비교적 쉽게 상악골과 구개를 재건할 수 있는 재건술로 널리 이용되고 있다. 장골능 유리 피판은 다 른 혈관성 골 유리 피판보다 일찍 개발되어 오랫동안 사용되
었고, 비골(fibula) 유리 피판보다 뼈의 양과 질에 있어 우수하 다는 장점이 있다.,10) 또 심장골 회선 동맥의 상행지(ascending branch of deep circumflex iliac artery)를 포함하면 내복사 근(internal oblique muscle)을 같이 채취할 수 있어, 구강 내 점막 결손의 동시 재건도 가능하며 피부 피판(skin graft)보다 조작하기 쉽고 생존 가능성이 크다. ${ }^{10)}$

장골능 유리 피판의 치명적인 단점은 혈관경의 길이가 짧 다는 것인데, 정맥 이식편(vein graft)을 이용하거나, 협부 피판 (cheek flap) 안쪽에서 불편하게 혈관 연결을 시행하여야 한 다. 공여부 이환율로는 보행장애, 탈장 등이 생길 수 있는데, 양측 피질골(bicortical) 전체 두께를 채취할 경우 위험이 증가 한다. ${ }^{11)}$ 탈장을 막기 위해 복벽 재건에 주의해야 하고, 정상적
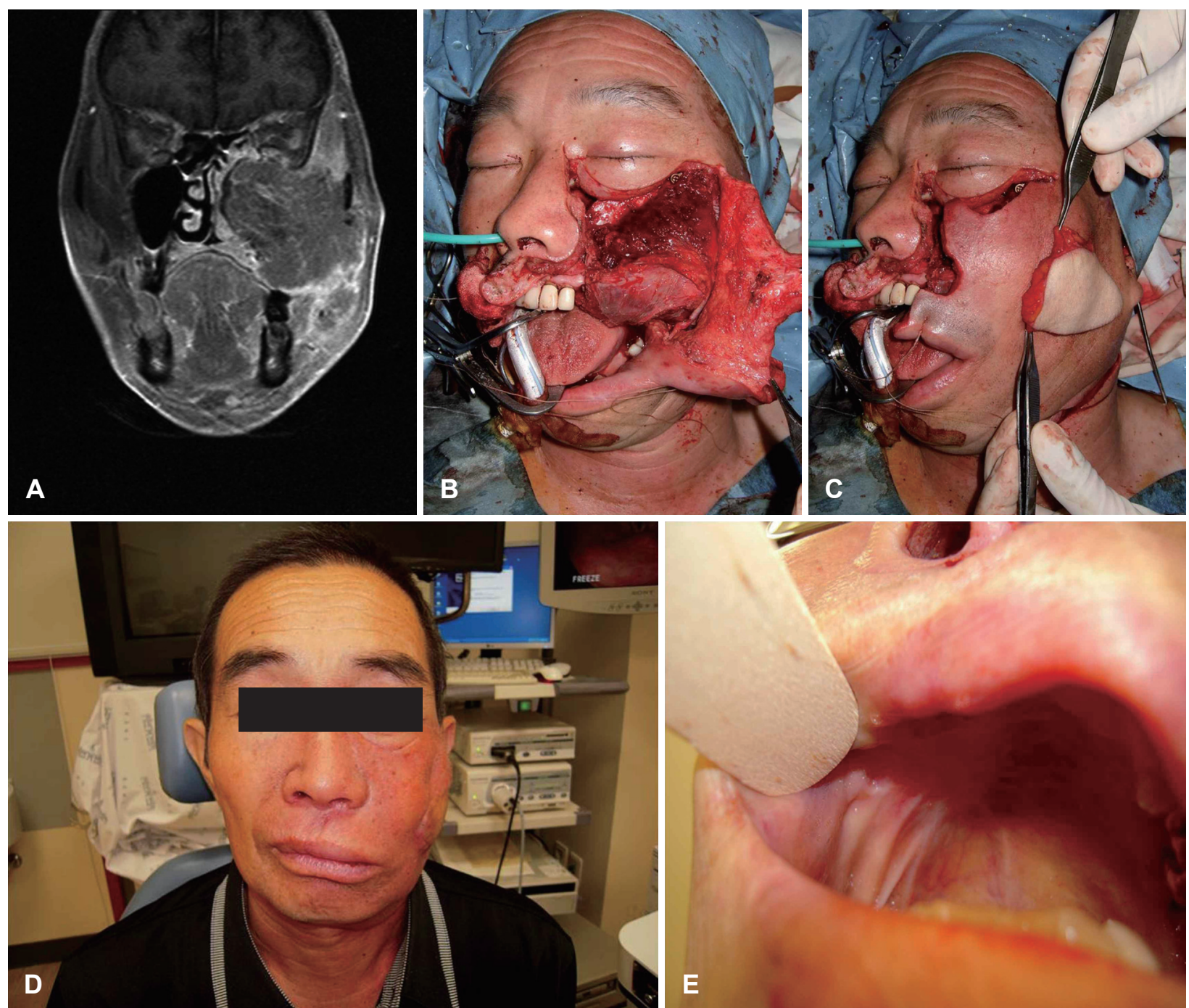

Fig. 2. Total maxillectomy and reconstruction with iliac crest osteomuscularcutaneous free flap. T1 enhance coronal shows enhancing mass with destruction of inferior wall of orbit and medial maxillary sinus walls, involvement of pterygopalatine fossa, premaxillary subcutaneous layer, buccal space, without definite involvement of orbital fat (A). After left total maxillectomy, ipsilateral supraomohyoid neck dissection and skin excision of tumor invasion, maxillary reconstruction with right iliac crest osteomuscularcutaneous free flap was performed (B and C). Postoperative patient photo at 8 weeks postoperatively (D). Internal oblique muscle of iliac crest thinned and reconstructed the palate defect with complete mucosalization at postoperative 6 month (E). 
인 보행을 위해 재활이 필요하다. CT 혈관 조영술 연구에 의 하면 $40 \%$ 에서는 피부로의 적당한 천공지가 관찰되지 않는다 고 하므로, ${ }^{22}$ 피부판을 같이 채취하고자 할 때는 수술 전 미리 CT 혈관 조영술을 시행할 필요가 있다.

상악 재건에 있어 가장 유리한 유리 피판에 대해 아직 합의 된 바가 없다. 우선 안구 적출 여부에 따라 그 피판을 선택하 며 안구 적출시 발생하는 넓은 결함은 근육과 지방이 풍부한 광배근 피판이나 복직근 피판으로 재건하는 것이 유리하다. 안구 보존시, 다음으로 치조 능선 재건 여부에 따라 그 피판을 선택하며 치조 능선 재건시 골과 근육 조직을 적절히 포함하 는 장골능 유리 피판이 보다 유용하다. 장골능 유리 피판은 다 른 피판보다 혈관경이 짧다는 단점만 극복한다면 다른 피판 보다 조작하기 쉽고 생존 가능성이 크며 구강 내 점막 결손을 회복하기 쉬우며 향후 치아 이식이 가능하기 때문에 골 결손 이 동반된 상악재건술의 좋은 선택이 될 것이다.

\section{REFERENCES}

1) Genden EM, Okay D, Stepp MT, Rezaee RP, Mojica JS, Buchbinder $\mathrm{D}$, et al. Comparison of functional and quality-of-life outcomes in patients with and without palatomaxillary reconstruction: a preliminary report. Arch Otolaryngol Head Neck Surg 2003; 129(7):775-80.

2) Andrades P, Militsakh O, Hanasono MM, Rieger J, Rosenthal EL. Current strategies in reconstruction of maxillectomy defects. Arch Otolaryngol Head Neck Surg 2011;137(8):806-12.
3) Brown JS, Shaw RJ. Reconstruction of the maxilla and midface: introducing a new classification. Lancet Oncol 2010;11(10):1001-8.

4) Santamaria E, Cordeiro PG. Reconstruction of maxillectomy and midfacial defects with free tissue transfer. J Surg Oncol 2006;94(6): $522-31$.

5) McCarthy CM, Cordeiro PG. Microvascular reconstruction of oncologic defects of the midface. Plast Reconstr Surg 2010;126(6): 1947-59.

6) Brown JS, Rogers SN, McNally DN, Boyle M. A modified classification for the maxillectomy defect. Head Neck 2000;22(1): 17-26.

7) Klug C, Berzaczy D, Voracek M, Enislidis G, Rath T, Millesi W, et al. Experience with microvascular free flaps in preoperatively irradiated tissue of the oral cavity and oropharynx in 303 patients. Oral Oncol 2005;41(7):738-46.

8) Cordeiro PG, Santamaria E. A classification system and algorithm for reconstruction of maxillectomy and midfacial defects. Plast Reconstr Surg 2000;105(7):2331-46; discussion 2347-8.

9) Brown JS. Deep circumflex iliac artery free flap with internal oblique muscle as a new method of immediate reconstruction of maxillectomy defect. Head Neck 1996;18(5):412-21.

10) Urken ML, Vickery C, Weinberg H, Buchbinder D, Lawson W, Biller HF. The internal oblique-iliac crest osseomyocutaneous free flap in oromandibular reconstruction. Report of 20 cases. Arch Otolaryngol Head Neck Surg 1989;115(3):339-49.

11) Hartman EH, Spauwen PH, Jansen JA. Donor-site complications in vascularized bone flap surgery. J Invest Surg 2002;15(4):185-97.

12) Ting JW, Rozen WM, Grinsell D, Stella DL, Ashton MW. The in vivo anatomy of the deep circumflex iliac artery perforators: defining the role for the DCIA perforator flap. Microsurgery 2009;29(4): 326-9. 